\title{
Taxonomic profile of bacterial communities detected with 16S-rRNA in mature phototrophic and heterotrophic marine biofilms used for aquaculture
}

\section{Perfil taxonómico de comunidades bacterianas detectadas con 16S-ARNr en biopelículas marinas autotróficas y heterotróficas utilizadas en la acuacultura}

\author{
Luis Rafael Martínez-Córdova ${ }^{1}$, Marcel Martínez-Porchas²*, Francisco Vargas-Albores ${ }^{2}$, \\ Anselmo Miranda-Baeza ${ }^{3}$, Mauricio Coelho-Emerenciano ${ }^{4}$, Marco Antonio Porchas-Cornejo ${ }^{5}$, \\ Edilmar Cortes-Jacinto ${ }^{6}$, Miguel Ángel Mazorra-Manzano ${ }^{2}$ \\ 1 Departamento de Investigaciones Científicas y Tecnológicas de la Universidad de Sonora, Universidad de \\ Sonora, Hermosillo, Sonora, Mexico. \\ 2 Departamento de Tecnología de Alimentos de Origen Animal, Centro de Investigación en Alimentación y \\ Desarrollo, A.C., Hermosillo, Sonora, Mexico. \\ 3 Universidad Estatal de Sonora, Navojoa, Sonora, Mexico. \\ 4 Centro de Educacao Superior da Regiao Sul, Universidade Estadual de Santa Catarina, Laguna, Santa \\ Catarina, Brazil. \\ 5 Centro de Investigaciones Biológicas del Noroeste, Unidad Guaymas, Guaymas, Sonora, Mexico. \\ ${ }^{6}$ Centro de Investigaciones Biológicas del Noroeste, Unidad La Paz, La Paz, Baja California, Mexico.
}

* Corresponding author: marcel@ciad.mx

\begin{abstract}
Bacterial diversity of phototrophic (PAb) and heterotrophic (Hb) biofilms was studied over time (0, 15 and 30 days of culture) using high throughput sequencing and considering the V3 and V4 hypervariable regions of the 16S rRNA gene. Bacterial composition in terms of relative abundance and diversity showed slight changes during the trial. Proteobacteria was the most abundant phylum in both biofilms during the experimental period. Chlamidiae-Verrucomicrobia, Bacteriodetes, and Planctomycetes were also abundant phyla in the PAb, whereas Planctomycetes, Bacteriodetes, Actinobacteria, and Chlamydiae were the abundant phyla in the Hb. Of the reads assigned up to species level, a total of 27 heterotrophic and autotrophic species were detected in both biofilms, most of them associated with the metabolism of nitrogenous and sulfurous metabolites and organic matter, and the rest with the structural functions in the biofilm. This is the first time some of these species have been reportedly detected in these biofilms or in the marine environment. Results suggest complex interaction networks in microbial conglomerates formed in biofilms, in which bacterial populations seem to play important metabolic and physiological roles.
\end{abstract}

Keywords: autotrophic biofilm, heterotrophic biofilm, microbial-based systems, targeted metagenomics, taxonomic classification

RESUMEN. Se estudió la diversidad de bacterias de biopelículas fototróficas (PAb) y heterotróficas (Hb) a través del tiempo (0, 15 y 30 días de cultivo) por medio de secuenciación masiva, considerando las regiones hipervariables V3 y V4 del gen 16S ARNr. La composición bacteriana mostró pequeños cambios durante el ensayo en términos de abundancia relativa y diversidad. Proteobacteria fue el filo más abundante en ambas biopelículas durante el experimento. Chlamidiae-Verrucomicrobia, Bacteriodetes y Planctomycetes también fueron filos abundantes en PAb, mientras que Planctomycetes, Bacteriodetes, Actinobacteria y Chlamydiae se registraron en $\mathrm{Hb}$. De las lecturas asignadas a nivel de especie, un total de 27 especies autrotróficas y heterotróficas fueron detectadas en ambas biopelículas, la mayoría de ellas asociadas al metabolismo de compuestos nitrogenados y azufrados y a materia orgánica, y las restantes asociadas a las funciones estructurales en las biopelículas. Esta es la primera vez que se reporta la detección de algunas de estas especies en estas biopelículas e incluso en el ambiente marino. Los resultados sugieren la existencia de complejas redes de interacción en los conglomerados microbianos formados en las bipelículas, en las cuales las poblaciones bacterianas parecen jugar papeles metabólicos y fisiológicos importantes.

Palabras clave: biopelícula autotrófica, biopelícula heterotrófica, sistemas basados en microbios, metagenómica dirigida, clasificación taxonómica.

\section{INTRODUCTION}

Molecular fouling is a ubiquitous phenomenon in aquatic ecosystems and aquaculture systems. When surfaces are submerged in seawater, dissolved organic matter adheres to these surfaces in just seconds, in a process termed molecular biofouling, forming a thin film $(\approx 100 \mathrm{~nm})$ that promotes the colonization of various microorganisms from diverse taxa (Qian

\section{INTRODUCCIÓN}

La agregación molecular puede ser considerada como un fenómeno ubicuo en ecosistemas acuáticos o acuícolas. Cuando una superficie es sumergida en agua marina, la materia orgánica disuelta se adhiere a la superficie en cuestión de segundos, en un proceso conocido como agregación molecular, y forma una película delgada $(\approx 100 \mathrm{~nm})$ que 
et al. 2007). Consequently, molecular fouling is rapidly followed by a biofouling process, in which these microorganisms begin to form a microbial community or biofilm. A microbial biofilm could be defined as an aggregate of diverse microorganisms belonging to diverse domains embedded within a self-produced matrix of extracellular polymeric substance adhered to each other and/or to a surface (Vert et al. 2012).

Both phototrophic- and heterotrophic-biofilm-based systems have been successfully used in aquaculture (Ballester et al. 2007, Becerra-Dorame et al. 2011) for diverse purposes, including bioremediation, probiotic activity, and, more recently, as a direct food source (Martínez-Córdova et al. 2014). Recent reports revealed that the use of these microbial communities may improve not only the water quality in shrimp culture systems, but also the growth performance and the physiological conditions of shrimp (Martínez-Córdova et al. 2014, Sruthisree et al. 2015). There is evidence that biofilms are constituted by bacteria, archaea, microalgae, organic and inorganic matter, and exopolymeric substances, as well as other microorganisms in lower proportions (Tolker-Nielsen and Molin 2000). From these, bacteria are perhaps the most important constituents because of their roles in the adherence of the biofilm to the surface, and in the complex interaction network occurring within the microbial community (Avendaño-Herrera and Riquelme 2007, Roeselers et al. 2008).

Several studies have been performed to elucidate the bacterial diversity of biofilms (Tolker-Nielsen and Molin 2000, Donlan 2002). Most bacteria thriving in biofilm microbial communities are usually identified through microscopic, biochemical, or molecular-based methods, such as restriction fragment length polymorphism (RFLP), denaturing gradient gel electrophoresis (DGGE), and other approaches (Bourne et al. 2004, Becerra-Dorame et al. 2011). Culture-dependent methods have been useful for the study of bacterial communities; however, the diversity of microorganisms in aquaculture has been elucidated in a very small fraction of bacterial communities, because $85-99 \%$ of the bacteria from the marine environment are not readily culturable or are simply unculturable (Martinez-Porchas and Vargas-Albores 2015). On the other hand, RFLP and DGGE reveal the presence of a major proportion of some species, but with lower resolution in terms of detectable limits compared to next-generation sequencing (NGS) technologies (Al-Awadhi et al. 2013).

A higher resolution of the bacterial community composition in biofilms used for aquaculture purposes could provide useful information, considering that bacteria-bacteria and (micro)algae-bacteria interactions include signal transduction, gene transfer, and nutrient exchange (Kouzuma and Watanabe 2015), which contributes to the success of these microbial communities. Moreover, this information may reveal differences in the taxonomic profile between both autotrophic- and heterotrophic-based biofilms, which is also relevant from a bioremediation perspective since microbial conglomerates take up and recycle nutrients or "wastes" produced by cultured organisms. promueve la colonización de microorganismos específicos de diversos grupos taxonómicos (Qian et al. 2007). Consecuentemente, la agregación molecular es rápidamente seguida por un proceso de agregación biológica, en el cual los microorganismos comienzan a formar comunidades microbianas o biopelículas. Las biopelículas pueden ser definidas como un agregado de diversos microorganismos pertenecientes a diversos dominios, embebidos dentro de una matriz producida por ellos mismos debido a la secreción de polímeros extracelulares adheridos unos a otros o a una superficie sumergida (Vert et al. 2012).

Las biopelículas basadas en organismos fototróficos y las biopelículas basadas en organismos heterotróficos han sido utilizadas exitosamente en la acuacultura (Ballester et al. 2007, Becerra-Dorame et al. 2011) para diversos propósitos, los cuales incluyen la bioremediación, la actividad probiótica y, recientemente, como fuente directa de alimento (Martínez-Córdova et al. 2014). Estudios recientes revelan que el uso de estas comunidades microbianas puede mejorar no solo la calidad del agua en cultivos camaronícolas, sino además el desempeño en cuanto a crecimiento y la condición fisiológica de los camarones cultivados. (Martínez-Córdova et al. 2014, Sruthisree et al. 2015). Existe evidencia que indica que las biopelículas están formadas por bacterias, arqueas, microalgas, materia orgánica e inorgánica, sustancias exopoliméricas y, en menor proporción, otros microorganismos (Tolker-Nielsen y Molin 2000). De estos microorganismos, las bacterias son desde luego los constituyentes más importantes debido a sus roles en la adherencia de la biopelícula a la superficie colonizada, y en la compleja red de interacciones que ocurren dentro del consorcio microbiano (Avendaño-Herrera y Riquelme 2007, Roeselers et al. 2008).

Varios estudios han sido llevados a cabo para elucidar la diversidad bacteriana de las biopelículas (Tolker-Nielsen y Molin 2000, Donlan 2002). La mayoría de las bacterias que forman parte de las comunidades microbianas en las biopelículas son usualmente identificadas a través de microscopía, métodos bioquímicos o métodos moleculares, como el análisis de fragmentos de restricción de longitud polimórfica (RFLP, por sus siglas en inglés), la electroforesis en gel desnaturalizante en gradiente (DGGE, por sus siglas en inglés) y otras aproximaciones (Bourne et al. 2004, Becerra-Dorame et al. 2011). Los métodos que dependen de cultivos han sido exitosamente utilizados para el estudio de comunidades bacterianas; sin embargo, la diversidad de microorganismos en cultivos acuícolas ha sido elucidada en una proporción muy pequeña de comunidades, debido a que entre el $85 \%$ y el $99 \%$ de las bacterias de ambientes marinos no son del todo cultivables o absolutamente no son cultivables (Martinez-Porchas y Vargas-Albores 2015). Por otro lado, los análisis de RFLP y DGGE revelan la presencia de una mayor proporción de algunas especies, pero tienen menor resolución en términos de los límites detectables en comparación con las tecnologías de secuenciación de nueva generación (NGS) (Al-Awadhi et al. 2013). 
NGS is a useful tool for obtaining this information and could provide an insight into the bacterial diversity of the microbial consortia through analysis of the hypervariable regions of the prokaryote 16S rRNA genes (Martinez-Porchas and Vargas-Albores 2015). 16S rRNA genes have at least one copy per genome, and 9 hypervariable regions have been detected that show considerable sequence diversity among bacteria. For instance, NGS has been used to study bacterial communities (including biofilms) in urban drinking water (Wu et al. 2015) and biofilms detected in fish processing plants (Langsrud et al. 2016), but not yet in marine biofilms with aquaculture purposes.

The aim of this study was to evaluate the taxonomic profiles of the bacterial communities detected, with 16S rRNA sequences, in mature phototrophic and heterotrophic marine biofilms used for aquaculture, to elucidate the bacterial community structure of these conglomerates.

\section{MATERIALS AND METHODS}

\section{Biofilm culture}

Autotrophic and heterotrophic biofilms were promoted and matured into six 200-L plastic tanks. These types of biofilms have been previously used as a direct food source for shrimp cultured under laboratory conditions with successful results (Becerra-Dorame et al. 2011, Becerra-Dorame et al. 2014).

The conditions for the proliferation of the biofilms were as follows: tanks were filled with $180 \mathrm{~L}$ of marine water taken from an estuary and previously filtered through a sand filter. Constant aeration was provided by diffusers placed at the bottom of the tanks. Artificial substrates consisting of plastic mesh-16 were placed vertically into each tank, and a surface:volume ratio of $5.6 \mathrm{~m}^{2}$ of substrate per square meter of water was achieved. Thereafter, tanks were randomly divided into groups to test 2 different types of biofilms ( 3 tanks/biofilm type): phototrophic biofilm (PAb) and a heterotrophic biofilm $(\mathrm{Hb})$. The formation of both biofilms was based on unspecific marine microorganisms already present in the marine water.

For PAb, a carbon:nitrogen ratio of 5:1 was maintained in the water by the periodic addition of Triple-17 fertilizer (17\% nitrogen, $17 \%$ phosphorous, $17 \%$ potassium). The quantification of carbon and nitrogen was performed spectrophotometrically (Hanna Instruments, NE, USA) to calculate the amount of fertilizer to be added. The tanks were exposed to outdoor conditions, including sunlight, and inoculated with $1 \mathrm{~L}\left(1 \times 10^{6}\right.$ cells $\left./ \mathrm{mL}\right)$ of the marine benthic diatom Navicula sp. Temperature was maintained at $30^{\circ} \mathrm{C}$, dissolved oxygen at $4-7 \mathrm{mg} / \mathrm{L}, \mathrm{pH}$ at $8.5-9.0$, and light intensity at $340-1,020 \mathrm{umol} / \mathrm{m}^{2} \cdot \mathrm{s}$. The diatom Navicula sp. was previously grown under laboratory conditions using $1 \mathrm{~L}$ Erlenmeyer flasks with sterile marine water and $\mathrm{f} / 2$ media (Guillard 1975) and was used as the biofilm promoter (Martínez-Córdova et al. 2017).
Una mayor resolución de la composición de las comunidades bacterianas en biopelículas usadas para propósitos acuaculturales puede proveer información relevante, considerando que las interacciones bacteria-bacteria y microalga-bacteria incluyen las señales de transducción, transferencia de genes e intercambio de nutrientes (Kouzuma y Watanabe 2015), las cuales contribuyen al éxito de dichas comunidades microbianas. Además, esta información puede revelar diferencias en los perfiles taxonómicos entre biopelículas basadas en microorganismos foto-autotróficos y en microorganismos heterotróficos, lo cual es también relevante desde una perspectiva de bioremediación dado que los conglomerados microbianos toman y reciclan nutrientes o "desechos" producidos por los organismos cultivados.

La NGS puede representar una herramienta útil para obtener esta información y puede proveer un conocimiento más profundo sobre la diversidad de los consorcios a través del análisis de las regiones hipervariables del gen 16S rRNA de procariotas (Martinez-Porchas y Vargas-Albores 2015). Los genes 16S rRNA tienen al menos una copia por genoma y han sido detectadas 9 regiones hipervariables que demuestran una considerable diversidad de secuencias entre bacterias. La NGS ha sido utilizada, por ejemplo, en estudios sobre la comunidad bacteriana (incluidas las biopelículas) de aguas para consumo (Wu et al. 2015) y estudios sobre las biopelículas en plantas de procesamiento de peces (Langsrud et al. 2016), pero no aún en biopelículas marinas con propósitos acuaculturales.

El objetivo de este estudio fue evaluar los perfiles taxonómicos de las comunidades bacterianas detectadas con 16S-rRNA en biopelículas maduras de microorganismos foto-autotróficos y heterotróficos usados para acuacultura para conocer la estructura de la comunidad microbiana de estos consorcios.

\section{MATERIALES Y MÉTODOS}

\section{Cultivo de biopelículas}

Las biopelículas autotróficas y heterotróficas fueron promovidas y maduradas en 6 tanques de plástico de $200 \mathrm{~L}$. Estos tipos de biopelículas han sido utilizados previamente como alimento directo para camarón cultivado bajo condiciones de laboratorio con resultados exitosos (Becerra-Dorame et al. 2011, Becerra-Dorame et al. 2014).

Las condiciones para la proliferación de los microorganismos fueron las siguientes: los tanques fueron llenados con $180 \mathrm{~L}$ de agua marina tomada de un estuario y filtrada a través de filtros de arena. Se proveyó aireación constante por medio de piedras difusoras en el fondo de los tanques. Sustratos artificiales que consistieron de red plástica con tamaño de malla 16 fueron colocados verticalmente en cada tanque, considerando una superficie/volumen de $5.6 \mathrm{~m}^{2}$ de sustrato por cada metro cúbico de agua. Los tanques fueron asignados al azar en grupos para analizar 2 tipos 
For $\mathrm{Hb}$, a carbon:nitrogen ratio of 20:1 (Avnimelech 1999) was used. Briefly, molasses was added as a carbon source to maintain an organic carbon concentration of $\sim 20 \mathrm{mg} / \mathrm{L}$. The organic carbon levels were monitored by a Torch Combustion TOC Analyzer (Teledyne-Tekmark; OH, USA). Temperature and dissolved oxygen were set to similar levels as those for the PAb, but the $\mathrm{pH}$ range was 7.5-8.0. A carbon:nitrogen:phosphorous ratio of 20:3:1 was maintained by adding $2 \mathrm{~mL}$ molasses, $2 \mathrm{~g} \mathrm{NaNO}_{3}$ and $\left(\mathrm{NH}_{4}\right)_{2} \mathrm{SO}_{4}$, and $0.05 \mathrm{~g} \mathrm{~K}_{2} \mathrm{HPO}_{4}$.

Biofilms were allowed to grow for 30 days prior to the trial. Water loss due to evaporation prior and during the trial was compensated for using sterile and ultrapure freshwater previously autoclaved and treated with a Milli-Q integral water purification system (Millipore; MA, USA) to avoid contamination of the system with other live microbes. Once the biofouling occurred and biofilms were attached to the substrates ( 40-60 mg of biofilm per square centimeter), samples were taken at 0,15 , and 30 days.

\section{Taxonomic profile of bacterial communities}

Bacteria present in the biofilms were detected through a targeted-metagenomic approach using the high throughput sequencing of the 16S rRNA gene, which was used as a taxonomic biomarker.

Samples were collected from each treatment and the DNA was isolated. Briefly, samples were obtained by scratching the surface of the plastic substrate and washed with sterile, nuclease-free water (Promega, USA) to eliminate possible unattached-planktonic bacteria. Samples from each biofilm group were pooled and homogenized at $6 \mathrm{~m} / \mathrm{s}$ for $30 \mathrm{~s}$ using a FastPrep-24 5G homogenizer (MP Biomedicals; CA, USA).

Randomly-sheared, high-molecular-weight metagenomic DNA (free of PCR inhibitors) directly from culturable and unculturable bacteria was isolated following the specifications of a commercial kit (Power Biofilm DNA isolation kit, MO BIO Laboratories; CA, USA). The DNA quality was monitored by a microfluidic electrophoresis instrument (2200 Tapestation, Agilent; CA, USA). Briefly, $1 \mu \mathrm{L}$ of the DNA isolate was mixed with $10 \mu \mathrm{L}$ of the gDNA sample buffer (Agilent). Of this mixture, $1 \mu \mathrm{L}$ per sample was added to a microfluidic chip (gDNA ScreenTape, Agilent) to assess the quantity and quality of DNA (range: 200 to $>60,000 \mathrm{bp}$ DNA fragments). The gDNA Ladder (Agilent) was used as the reference. Samples with DNA integrity numbers above 7 were considered for the construction of a library. Additionally, DNA was extracted following the specifications of the Meta-G-Nome DNA isolation kit (Epicentre; CA, USA) from the marine water used to grow both biofilms.

\section{Library preparation}

16S-metagenomic library preparation was carried out following the "16S-metagenomic sequencing library de biopelículas (3tanques/tipo de biopelícula): biopelícula autotrófica (PAb) y biopelícula heterotrófica $(\mathrm{Hb})$. La formación de las biopelículas fue originada de microorganismos inespecíficos ya presentes en el agua suplementada.

Para PAb, una proporción de carbono: nitrógeno de 5:1 fue mantenida en la columna de agua mediante la adición periódica de fertilizante Triple-17 (17\% nitrógeno, 17\% fósforo y $17 \%$ potasio). La cuantificación de nitrógeno y carbono se realizó espectrofotométricamente por separado (Hanna Instruments, NE, UEA) para calcular la cantidad de fertilizante a añadir. Estos tanques fueron expuestos a la intemperie, bajo luz directa del sol, e inoculados con $1 \mathrm{~L}\left(1 \times 10^{6}\right.$ cél $\left./ \mathrm{mL}\right)$ de la diatomea bentónica Navicula sp. La temperatura se mantuvo a alrededor de $30^{\circ} \mathrm{C}$, el oxígeno disuelto a $4-7 \mathrm{mg} / \mathrm{L}$, el pH a $8.5-9.0$ y la intensidad luminosa a $340-1,020 \mathrm{umol} / \mathrm{m}^{2} \cdot \mathrm{s}$. La diatomea Navicula sp. fue previamente cultivada en el laboratorio en frascos Erlenmeyer de $1 \mathrm{~L}$ con agua marina estéril y el medio f/2 (Guillard 1975), para luego ser usada como promotor de las biopelículas (Martínez-Córdova et al. 2017).

Para $\mathrm{Hb}$, la proporción de carbono:nitrógeno fue mantenida en alrededor de 20:1 (Avnimelech 1999). Brevemente, se usó melaza para mantener una concentración de carbón orgánico de $\sim 20 \mathrm{mg} / \mathrm{L}$. Estos niveles fueron medidos por medio de un equipo de combustión TOC Torch (Teledyne-Tekmark; OH, EUA). La temperatura y el oxígeno disuelto fueron mantenidos a niveles similares que aquellos para PAb, pero el intervalo del $\mathrm{pH}$ fue de 7.5-8.0. Una proporción carbono:nitrogeno:fósforo de 20:3:1 fue mantenida mediante la adición de $2 \mathrm{~mL}$ de melaza, $2 \mathrm{~g}$ de $\mathrm{NaNO}_{3}$ y $\left(\mathrm{NH}_{4}\right) 2 \mathrm{SO}_{4}$, y $0.05 \mathrm{~g}$ de $\mathrm{K}_{2} \mathrm{HPO}_{4}$.

Las biopelículas se mantuvieron creciendo por 30 días previo al inicio del ensayo. La pérdida de agua por evaporación antes y durante el estudio fue repuesta con agua dulce ultrapura, previamente esterilizada en autoclave y luego tratada con un sistema de purificación Milli-Q (Millipore; MA, EUA) para evitar la contaminación del sistema con otros microorganismos vivos. Una vez que ocurrió la adhesión y las biopelículas se pegaron a los sustratos ( $40-60 \mathrm{mg}$ de biopelícula por centímetro cuadrado), se tomaron muestras a los 0 , 15 y 30 días.

\section{Perfil taxonómico de la comunidad bacteriana}

Las bacterias presentes en las biopelículas fueron detectadas mediante la metagenómica dirigida, considerando la secuenciación masiva del gen $16 \mathrm{~S}$ ARNr, el cual fue utilizado como marcador taxonómico.

Las muestras fueron recolectadas de cada tratamiento y el ADN, aislado. Brevemente, las muestras fueron obtenidas mediante el raspado de las superficies plásticas y lavadas con agua estéril libre de nucleasas (Promega, EUA) para eliminar la posible contaminación por bacterias planctónicas no adheridas. Las muestras de cada grupo de biopelículas fueron combinadas y homogenizadas a $6 \mathrm{~m} / \mathrm{s}$ por $30 \mathrm{~s}$ en un homogeneizador FastPrep-24 5G (MP Biomedicals; CA, EUA). 
preparation guide" (Illumina 2013). In short, the protocol targets the 16S V3 and V4 regions together using the primers reported by Klindworth et al. (2012), modified with sequencing adapters and dual index barcodes: 16S Overhang adapter/Forward Primer: 5' TCGTCGGCAGCGTCAGATGTGTATAAGAGACAGCCTACGGGNGGCWGCAG 3'; 16S Overhang adapter/Reverse Primer: 5' GTCTCGTGGGCTCGGAGATGTGTATAAGAGACAGGACTACHVGGGTATCTAATCC 3'.

The first amplification of the V3/V4 region was carried out in $25 \mu \mathrm{L}$ reactions using $2 \times$ KAPA HiFi HotStart ReadyMix (KAPA Biosystems; MA, USA) under the following thermal cycling conditions: initial denaturation at $95{ }^{\circ} \mathrm{C}$ for $3 \mathrm{~min} ; 25$ cycles of $95{ }^{\circ} \mathrm{C}$ for $10 \mathrm{~s}, 55^{\circ} \mathrm{C}$ for $30 \mathrm{~s}, 72^{\circ} \mathrm{C}$ for $30 \mathrm{~s}$; and a final extension at $68^{\circ} \mathrm{C}$ for $5 \mathrm{~min}$. Amplicons ranging from 450 to $550 \mathrm{bp}$ were purified using magnetic AMPure XP beads (Beckman Coulter; FL, USA) to separate the $16 \mathrm{~S} \mathrm{~V} 3 / \mathrm{V} 4$ amplicon from free primers and primer dimer species, following the manufacturer's specifications. After isolation, the amplicons were attached with dual indexes and sequencing adapters using the Nextera XT Index Kit (Illumina; CA, USA) and 2× KAPA HiFi HotStart ReadyMix. The above thermal cycling conditions were performed for 8 cycles, and the resulting PCR products were purified as mentioned above.

Finally, the resulting library was quantified and the quality checked by electrophoresis (2200 Tapestation, Agilent; CA, USA) using microfluidic chips (with an analysis range of 35 to 1,000 bp fragments, D1000 ScreenTape, Agilent; CA, USA). Briefly, $2 \mu \mathrm{L}$ of the indexed-library was mixed with $2 \mu \mathrm{L}$ of High Sensitivity D1000 buffer. The samples were finally loaded into a High Sensitivity D1000 ScreenTape and analyzed by electrophoresis (2200 Tapestation).

\section{Sequencing}

Libraries were diluted to $4 \mathrm{nM}$ using $10 \mathrm{mM}$ Tris ( $\mathrm{pH} 8.5)$ and pooled. Thereafter, libraries were denatured with $0.2 \mathrm{~N}$ $\mathrm{NaOH}$. A standard PhiX Control Library (Illumina), which is a well-defined short genome sequence that allows for the calculation of error rates, was also denatured and used as an internal control.

Thereafter, both denatured libraries (sample and control) were adjusted to a final concentration of $8 \mathrm{pM}$ and mixed (95\% library $+5 \%$ PhiX Control). Finally, the mixture was heated to $96{ }^{\circ} \mathrm{C}$ for $2 \mathrm{~min}$, immediately cooled in ice for 5 min, and loaded into a MiSeq v3 Reagent Tray (Illumina). The tray was inserted into a MiSeq sequencing instrument (Illumina), which contained a MiSeq v3 Flow Cell (Illumina) with a capacity of 25 million reads. Results were obtained after $602(2 \times 301)$ cycles. Artificial replicate sequences were removed and the resulting paired-end reads were assembled. Thereafter, sequences were submitted to a dereplication process, followed by length (2.0 standard deviations) and ambiguous base filtering ( $\max$ ambiguous $b p=5$ ).
El ADN metagenómico de alto peso molecular y cizallado al azar (libre de inhibidores de PCR) directamente de bacterias cultivables y no cultivables fue aislado siguiendo las especificaciones del kit comercial (kit de aislamiento Power Biofilm DNA, MO BIO Laboratories; CA, EUA). La calidad del ADN fue monitoreada por medio de un equipo de electroforesis por microfluido (2200 Tapestation, Agilent; CA, EUA). Para ello, $1 \mu \mathrm{L}$ de la solución aislada de ADN fue mezclada con $10 \mu \mathrm{L}$ de la muestra amortiguadora de ADNg (Agilent). Para la mezcla, $1 \mu \mathrm{L}$ por muestra fue insertado en un chip de microfluido (gDNA ScreenTape, Agilent) para evaluar la cantidad y la calidad del ADN (intervalo: fragmentos de ADN de $200 \mathrm{a}>60,000 \mathrm{pb}$ ). El gDNA Ladder (Agilent) fue utilizado como referencia. Las muestras que registraron un número de integridad de ADN arriba de 7 fueron consideradas para construir las bibliotecas. Adicionalmente, se extrajo ADN de muestras de agua usada para la formación de los 2 tipos de biopelículas siguiendo las especificaciones del kit de aislamiento Meta-G-Nome DNA (Epicentre; CA, EUA).

\section{Preparación de bibliotecas}

La preparación de las bibliotecas de $16 \mathrm{~S}$ metagenómico se llevó a cabo siguiendo la guía " $16 \mathrm{~S}-$ metagenomic sequencing library preparation guide" (Illumina 2013). Brevemente, el protocolo se centra en las regiones $16 \mathrm{~S} \mathrm{~V} 3$ y V4 usando los cebadores reportados por Klindworth et al. (2012), pero conjuntados con adaptadores de secuencias e índices duales como códigos de barras: 16S Adaptador/Cebador Sentido: 5' TCGTCGGCAGCGTCAGATGTGTATAAGAGACAGCCTACGGGNGGCWGCAG 3'; 16S Adaptador/Cebador Anti-sentido: 5' GTCTCGTGGGCTCGGAGATGTGTATAAGAGACAGGACTACHVGGGTATCTAATCC 3'.

La primera amplificación de la región V3/V4 se llevó a cabo en una reacción de $25 \mu \mathrm{L}$ usando $2 \times$ KAPA HiFi HotStart ReadyMix (KAPA Biosystems; MA, EUA) bajo las siguientes condiciones de ciclos térmicos: desnaturalización inicial a $95{ }^{\circ} \mathrm{C}$ por $3 \mathrm{~min} ; 25$ ciclos a $95{ }^{\circ} \mathrm{C}$ por $10 \mathrm{~s}, 55^{\circ} \mathrm{C}$ por $30 \mathrm{~s}, 72{ }^{\circ} \mathrm{C}$ por $30 \mathrm{~s}$; y una extensión final a $68^{\circ} \mathrm{C}$ por 5 min. Los amplicones entre 450 y $550 \mathrm{pb}$ fueron sometidos a un procedimiento de purificación usando perlas magnéticas AMPure XP (Beckman Coulter; FL, EUA) para aislar los amplicones 16S V3/V4 de los cebadores libres y de dímeros de cebadores, siguiendo las especificaciones del fabricante. Después de aislarlos, los amplicones fueron asociados con adaptadores para índices duales y secuenciación usando el Nextera XT Index Kit (Illumina; CA, EUA) y $2 \times$ KAPA HiFi HotStart ReadyMix. Las condiciones de los ciclos térmicos mencionados arriba fueron utilizadas durante 8 ciclos, y las bibliotecas fueron purificadas repitiendo el mismo proceso.

Finalmente, las bibliotecas resultantes fueron cuantificadas y cualificadas por electroforesis (2200 Tapestation, Agilent; CA, EUA) usando chips para microfluidos (con un rango de análisis de fragmentos de 35 a $1,000 \mathrm{pb}$, D1000 ScreenTape, Agilent; CA, EUA). En forma resumida, $2 \mu \mathrm{L}$ de 


\section{Data analysis}

Sequences were submitted to the MG-RAST server platform and the default options for low-quality reads trimming and sequence screening was performed. Sequences outside the range of \pm 2 standard deviations were not considered for the analysis. The taxonomic classification and diversity analyses were performed by comparison against the SILVA (128) database using the MG-RAST pipeline, where tasks for detection, clustering at $97 \%$ similarity and RNA identification, annotation mapping, and abundance profiles were used. Principal component analysis was performed using the STAMP (statistical analysis of taxonomic and functional profiles) software (Parks et al. 2014). A repeated-measures analysis of variance was used for data analysis, considering relative abundance and time as factors, and a significance value of $P=0.05$. Finally, alpha and beta diversities were calculated using an analytic hierarchy method as described by Goepel (Goepel 2013).

\section{Results}

DNA extracted and purified from $\mathrm{PAb}$ and $\mathrm{Hb}$ registered DNA integrity number values above 8.4 and 7.4, respectively. After amplification, amplicons with sizes 501 to $540 \mathrm{bp}$ were obtained for both biofilms during the trial; the percentages of integrated area of these amplicons were $\geq 90.1$ and $\geq 89.4 \%$, for $\mathrm{PAb}$ and $\mathrm{Hb}$, respectively, whereas peak molarity values ranged from 3,050 to $3,700 \mathrm{pmol} / \mathrm{L}$

Averages of 1,010,601 and 496,259 reads were classified up to a taxonomic level in the PAb and $\mathrm{Hb}$ samples, respectively. Of these, $\sim 35-40 \%$ were classified up to genus or species level. Bacterial diversity remained constant in both biofilms with respect to time (with a few exceptions); on the other hand, the relative abundance of the most representative bacteria did not register significant changes, except for a few specimens that varied over time $(P<0.05)$ (Table 1, Fig. 1). Herein, alpha diversity changed over time, revealing a loss of species in the PAb, and a gain of species in the case of the $\mathrm{Hb}$ (Table 2). Proteobacteria represented the most abundant phylum in both biofilms during the experimental period. Herein, $48 \%$ and $36 \%$ of the analyzed reads of PAb and $\mathrm{Hb}$ during the 3 sampling dates corresponded to Proteobacteria (Fig. 1). Most of these reads were assigned to the Alpha-, Beta-, or Gamma-Proteobacteria class in the 2 different biofilms. After Proteobacteria, Chlamidiae-Verrucomicrobia $(11 \%)$, Bacteriodetes $(8 \%)$, and Planctomycetes $(5 \%)$ were the most abundant phyla in the PA biofilm, whereas Planctomycetes (22\%), Bacteriodetes (8\%), Actinobacteria (6\%), and Chamydiae (2\%) were found in the $\mathrm{Hb}$ (Fig. 1). Several other phyla were detected in both biofilms but in lower proportions $(<1 \%)$.

Different bacterial profiles, in terms of relative abundance and detection of particular species, were observed in the 2 different biofilms (Fig. 2). Of the reads assigned to the species la biblioteca indizada fueron mezclados con $2 \mu \mathrm{L}$ del amortiguador High Sensitivity D1000. Las muestras fueron finalmente descargadas en un analizador de electroforesis High Sensitivity D1000 ScreenTape (2200 Tapestation).

\section{Secuenciación}

Las bibliotecas fueron diluidas a $4 \mathrm{nM}$ usando $10 \mathrm{mM}$ Tris $(\mathrm{pH}$ 8.5) y conjuntadas. Posteriormente, fueron desnaturalizadas con $0.2 \mathrm{~N} \mathrm{NaOH}$. El estándar PhiX Control Library (Illumina), que es una secuencia genómica corta bien definida que permite calcular los porcentajes de error, fue también desnaturalizado y usado como control interno.

Posteriormente, ambas bibliotecas desnaturalizadas (muestra y control) fueron ajustadas a la concentración final de 8 pM y mezcladas (95\% biblioteca $+5 \%$ PhiX Control). Finalmente, la muestra fue calentada a $96^{\circ} \mathrm{C}$ por 2 min e inmediatamente enfriada en hielo por 5 min y cargada al cartucho de reacción MiSeq v3 (Illumina). El cartucho fue insertado al equipo de secuenciación MiSeq (Illumina), que contenía una celda de flujo MiSeq v3 (Illumina) con capacidad de 25 millones de lecturas. Los resultados fueron obtenidos después de $602(2 \times 301)$ ciclos. Las réplicas de secuencias artificiales fueron removidas y las lecturas pareadas finales fueron ensambladas. Luego, las secuencias fueron sometidas al proceso de replicación, seguido por un proceso de filtrado de tamaño (2.0 desviaciones estándar) y bases ambiguas ( máxima ambigüedad $=5 \mathrm{pb}$ ).

\section{Análisis de datos}

Las secuencias fueron sometidas al servidor de la plataforma MG-RAST, y las opciones por defecto de eliminación de lecturas de baja calidad fueron establecidas. Las secuencias fuera del rango de la desviación estándar de \pm 2 no fueron consideradas en el análisis. La clasificación taxonómica y el análisis de diversidad se llevó a cabo mediante la comparación contra la base de datos SILVA (128) usando el proceso de MG-RAST, donde se llevaron a cabo las tareas de detección, el agrupamiento al 97\%, la identificación de ARN, la anotación por mapeo y los perfiles de abundancia. El análisis de componentes principales se realizó utilizando el software STAMP (por sus siglas en inglés, análisis estadístico de los perfiles taxonómicos y funcionales) (Parks et al. 2014). Un análisis de varianza de medidas repetidas se usó para el análisis de los datos considerando la abundancia relativa como factor, con un nivel de significación de $P=0.05$. Finalmente, la diversidad alfa y beta fueron calculadas usando un análisis de jerarquía propuesto por Goepel (Goepel 2013).

\section{RESUltados}

El ADN extraído y purificado de las biopelículas PAb y $\mathrm{Hb}$ registró números de integridad del ADN por arriba de 8.4 y 7.4, respectivamente. Después de la amplificación, los 
level, Ketogulonicigium vulgare, Rhodobacter capsulatus, Nitrosospira multiformis, Sulfiromonas autotrophica (all Proteobacteria), Simkania negevensis (Chlamydiae), Haliscomenobacter hydrossis, Echinicola vietnamensis (Bacteriodetes), Opitutus terrae (Verrucomicrobia), Planctomyces brasiliensis, and Rhodopirellula baltica (Planctomycetes) accounted for $89-94 \%$ of the reads in PAb during the trial (Table 1). For the $\mathrm{Hb}$, of the reads assigned to the species level, K. vulgare, Verminephrobacter eiseniae, S. autotrophica (all Proteobacteria), H. hydrossis (Bacteriodetes), P. brasiliensis (Planctomycetes), Microbacterium testaceum, and Tropheryma whipplei (Actinobacteria) accounted for 83-93\% of the reads (Table 1).

All the species detected in both biofilms were first detected in water in different proportions. Of the 36 species detected in water (with at least $1 \%$ of the reads classified to species), 27 were detected in both biofilms from at least one sampling date (Table 1). However, beta diversity analysis together with PCA revealed that the weighted taxonomic profile of both biofilms was diametrically different (Table 2, Fig. 3).

Some species were detected in all biofilm samples and others were exclusive for one biofilm type. For instance, $K$. vulgare, V. eiseniae, S. negevensis, H. hydrossis, $P$. brasiliensis, and Streptococcus agalactiae were detected in both phototrophic and heterotrophic biofilms (Table 3), with $K$. vulgare (21-43\%) and $H$. hydrossis (9-29\%) detected in high proportions in both biofilms.

Regarding bacteria exclusively detected in the phototrophic biofilm, species such as $N$. multiformis, E. vietnamensis, R. baltica, Saprospira grandis, and a candidate division WWE3 bacterium were observed (Table 3), whereas Micavibrio aeruginosavorus, Arcobacter sp. L, Hyphomonas neptunium, Riemerella anatipestifer, Phycisphaera mikurensis, Acetohalobium arabaticum, T. whipplei, M. testaceum, and Propionibacterium acidipropionici were exclusively detected in heterotrophic biofilms (Table 3).

\section{Discussion}

The results revealed that bacterial composition in terms of diversity and relative abundance was consistent over time for both biofilms. It is likely that the proliferation period prior to the trial (30 days) was sufficient for the microbial conglomerates to achieve a mature phase where the biofilm composition was less variable over time. Moreover, the constant experimental conditions could have contributed to maintaining a uniform composition.

Bacteria belonging to the Proteobacteria, Bacteroidetes, and Planctomycetes phyla seemed to form the core structure of both $\mathrm{Hb}$ and PAb (also Chlamydiae). Similar taxonomic structures have been reported in marine and freshwater biofilms (Salta et al. 2013, Besemer 2015).

The diversity of bacteria detected in the biofilms indicates the diverse biological functions of these microbial conglomerates and a very complex interaction network. There is amplicones con tamaños de 501 a $540 \mathrm{pb}$ fueron obtenidos para las 2 biopelículas durante la corrida; los porcentajes del área integrada de esos amplicones fueron $\geq 90.1$ y $\geq 89.4 \%$ para $\mathrm{PAb}$ y $\mathrm{Hb}$, respectivamente, mientras que los picos de molaridad variaron de 3,050 a 3,700 pmol/L.

Lecturas con promedios de 1,010,601 y 496,259 fueron clasificadas en algún nivel taxonómico en las biopelículas $\mathrm{PAb}$ y $\mathrm{Hb}$. De estas, el $\sim 35-40 \%$ fueron clasificadas a nivel de género o especie. La diversidad bacteriana permaneció constante en ambos tipos de biopelículas con respecto al tiempo (con pocas excepciones); por otro lado, la abundancia relativa de las bacterias más representativas no mostró cambios significativos, excepto algunos especímenes que variaron con el tiempo $(P<0.05)$ (Tabla 1, Fig. 1). En este sentido, la diversidad alfa reveló una pérdida de especies en PAb y un aumento en el número de especies en $\mathrm{Hb}$ (Tabla 2). Proteobacteria representó el filo más abundante en ambas biopelículas durante el estudio. Así, el $48 \%$ y el 36\% de las lecturas analizadas para PAb y Hb durante los 3 muestreos correspondieron a Proteobacteria (Fig. 1). La mayoría de esas lecturas fueron asignadas a las clases Alfa-, Beta- o Gama-Proteobacteria en los 2 tipos de biopelículas. Después de Proteobacteria, Chlamidiae-Verrucomicrobia (11\%), Bacteriodetes (8\%) y Planctomycetes (5\%) fueron los filos más abundantes en PAb, mientras que Planctomycetes (22\%), Bacteriodetes (8\%), Actinobacteria (6\%) y Chamydiae $(2 \%)$ fueron encontrados en $\mathrm{Hb}$ (Fig. 1). Varios otros filos fueron detectados en ambos tipos de biopelículas, pero en proporciones menores $(<1 \%)$.

Diferentes perfiles bacterianos en términos de abundancia relativa y presencia de especies particulares fueron observados en los 2 diferentes tipos de biopelículas (Fig. 2). De las lecturas asignadas a nivel de especie, Ketogulonicigium vulgare, Rhodobacter capsulatus, Nitrosospira multiformis, Sulfiromonas autotrophica (todas del filo Proteobacteria), Simkania negevensis (Chlamydiae), Haliscomenobacter hydrossis, Echinicola vietnamensis (Bacteriodetes), Opitutus terrae (Verrucomicrobia), Planctomyces brasiliensis y Rhodopirellula báltica (Planctomycetes) contaron para el $89-94 \%$ de las lecturas en PAb durante la corrida (Tabla 1). Para $\mathrm{Hb}$, de las lecturas asignadas a nivel de especie, K. vulgare, Verminephrobacter eiseniae, S. autotrophica (todas del filo Proteobacteria), H. hydrossis (Bacteriodetes), P. brasiliensis (Planctomycetes), Microbacterium testaceum y Tropheryma whipplei (Actinobacteria) representaron el $83-93 \%$ de las lecturas (Tabla 1).

Todas las especies detectadas en las biopelículas fueron detectadas primero en el agua en diferentes proporciones. De las 36 especies detectadas en agua (con al menos el 1\% de las lecturas clasificadas a nivel de especie), 27 fueron detectadas en las biopelículas en al menos una fecha de muestreo (Tabla 1). Sin embargo, el análisis de la diversidad beta, junto con el PCA, reveló que el peso del perfil taxonómico de ambas biopelículas fue diametralmente diferente (Tabla 2, Fig. 3). 
Table 1. Proportion of bacterial species detected in the phototrophic (PAb) and heterotrophic (Hb) biofilms over time (0, 15, and $30 \mathrm{~d})$. Proportions are based on the total reads assigned up to species level. $P$ values for biofilm type and time factors are also shown.

Tabla 1. Proporción de especies bacterianas detectadas en la biopelícula fototrófica $(\mathrm{PAb})$ y la biopelícula heterotrófica $(\mathrm{Hb})$ a través del tiempo $(0,15$ y 30 d). Las proporciones están basadas en el total de lecturas asignadas hasta nivel de especie. También se muestran los valores $P$ para los factores tipo de biopelícula y tiempo.

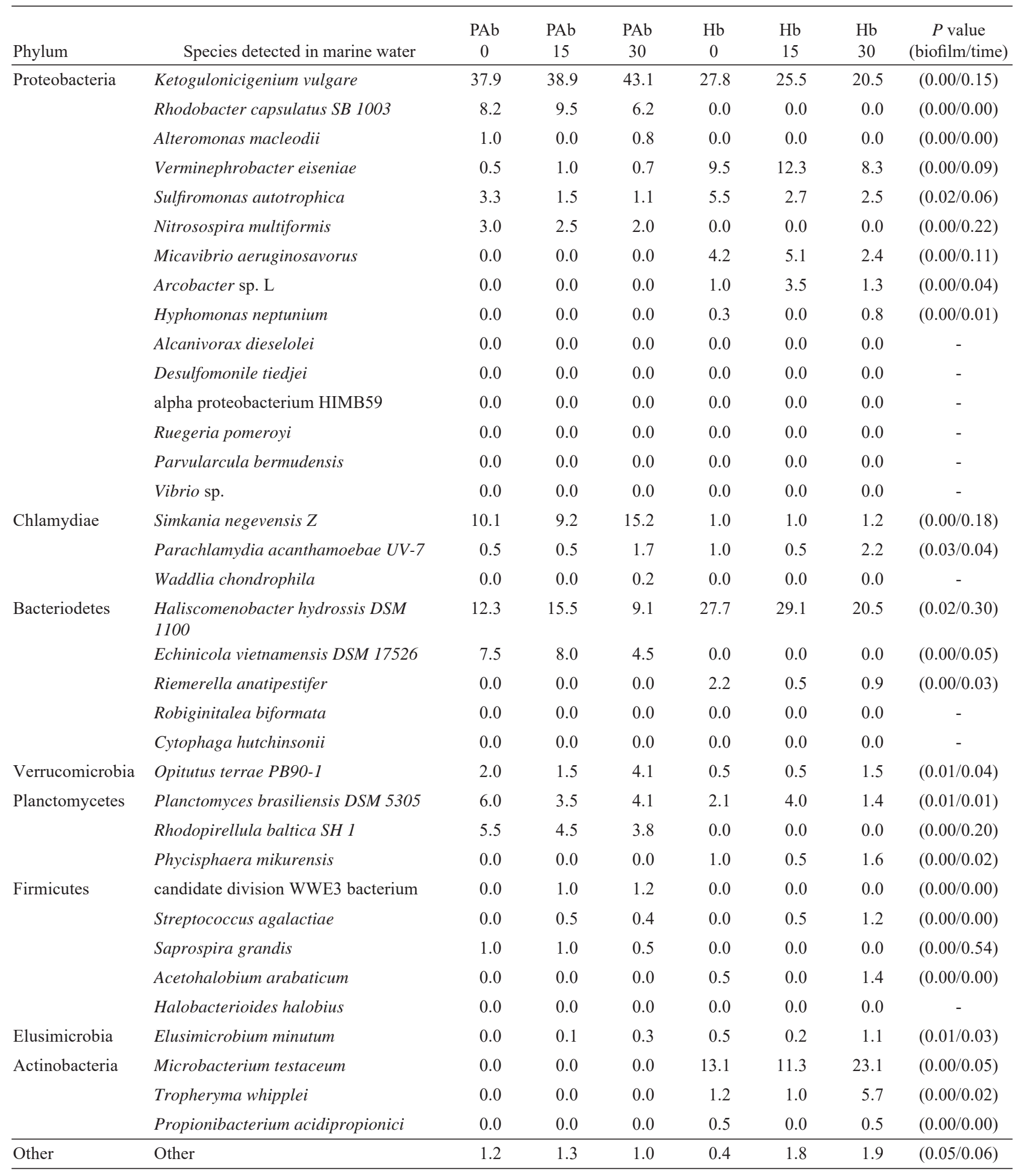



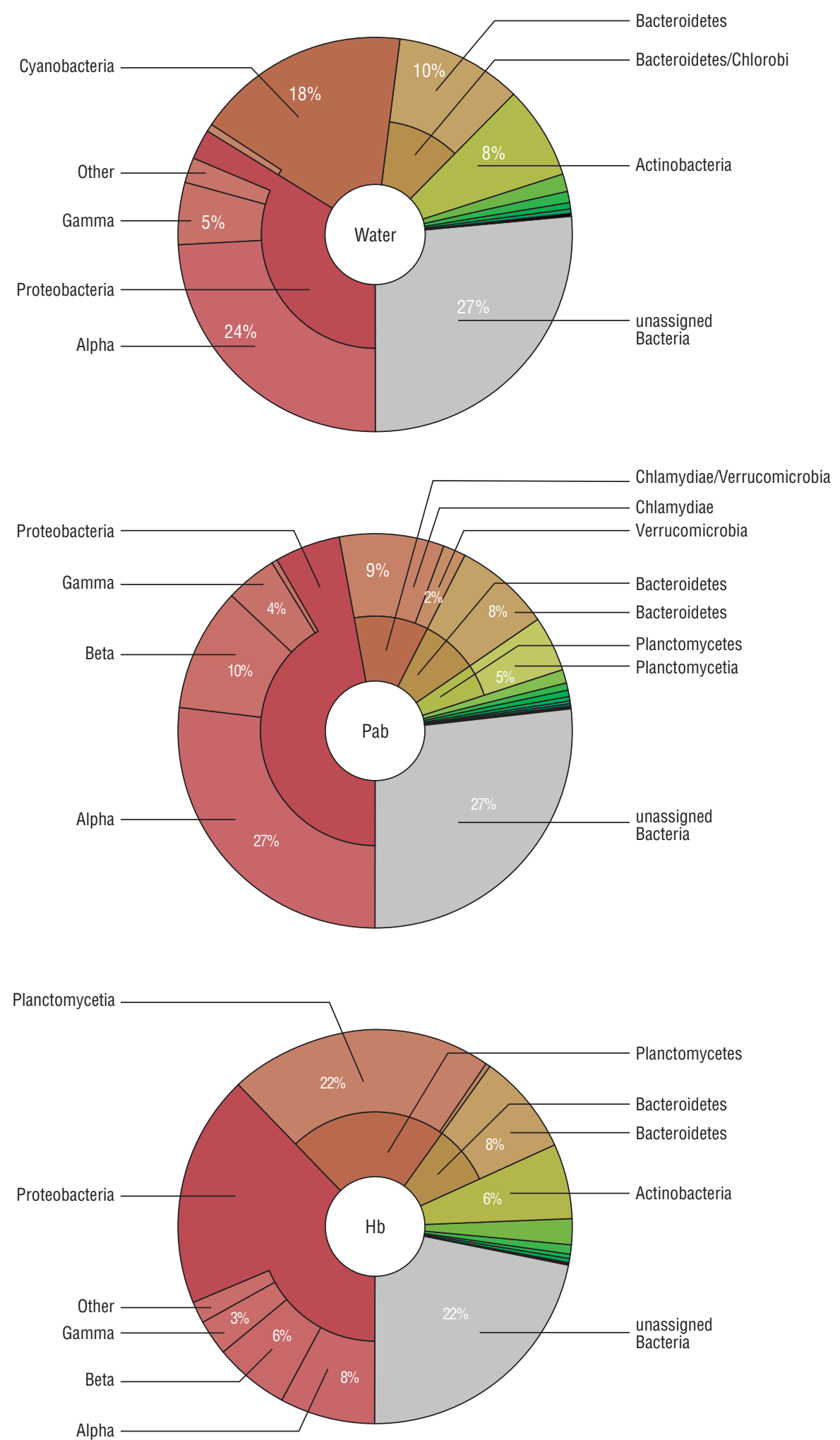

Figure 1. Taxonomic classification (phylum and class) of bacteria detected in water used for the biofilm culture, in the phototrophic biofilm $(\mathrm{PAb})$ and in the heterotrophic biofilm $(\mathrm{Hb})$.

Figura 1. Clasificación taxonómica (filo y clase) de bacterias detectadas en el agua utilizada para el cultivo de biopelículas, en las biopelículas fototróficas $(\mathrm{PAb})$ y en las biopelículas heterotróficas $(\mathrm{Hb})$. 
Table 2. Comparison matrix containing the alpha $(\alpha)$ and beta $(\beta)$ diversity values of phototrophic (PAb) and heterotrophic $(\mathrm{Hb})$ biofilms at 0,15 , and 30 days of culture.

Tabla 2. Matríz de comparación que contiene los valores de diversidad alfa $(\alpha)$ y beta $(\beta)$ de las biopelículas fototróficas $(\mathrm{PAb})$ y heterotróficas $(\mathrm{Hb})$ a los 0,15 y 30 días de cultivo.

\begin{tabular}{lcccccc}
\hline & PAb 0 & PAb 15 & PAb 30 & Hb 0 & Hb 15 & Hb 30 \\
\hline $\begin{array}{l}\beta \text {-Diversity } \\
\text { PAb 0 }\end{array}$ & 0.00 & 0.01 & 0.02 & 0.26 & 0.25 & 0.29 \\
PAb 15 & 0.01 & 0.00 & 0.02 & 0.25 & 0.24 & 0.28 \\
PAb 30 & 0.02 & 0.02 & 0.00 & 0.28 & 0.27 & 0.29 \\
Hb 0 & 0.26 & 0.25 & 0.28 & 0.00 & 0.02 & 0.05 \\
Hb 15 & 0.25 & 0.24 & 0.27 & 0.02 & 0.00 & 0.05 \\
Hb 30 & 0.29 & 0.28 & 0.29 & 0.05 & 0.05 & 0.00 \\
\hline$\alpha$-Diversity & 1.98 & 1.90 & 1.85 & 1.86 & 1.91 & 2.05 \\
\hline
\end{tabular}

evidence demonstrating that mature biofilms are still physiologically active and are not merely aggregates on surfaces (Watnick and Kolter 2000, Vargas-Albores et al. 2019).

Considerable differences were detected between the bacterial profiles of both biofilms; however, they shared 10 of the 27 species observed in all the samples. From these, $H$. hydrossis seems to play a major role in the biology and physical structure of both biofilms. This species was detected in high proportions in all biofilms and is strictly an aerobic (gram-negative), filamentous, biomass bulking bacterium (Kotay et al. 2011), which grows in strands or filaments rather than a floc; these filaments are reported to be abundant in aquatic systems with high surface:volume ratios (Kotay et al. 2011). In addition, this and other phylogenetically close bacteria have been reported to produce adhesin-like compounds (Larsen et al. 2008), which may enable tight attachments to submerged surfaces.

The high relative abundance of $K$. vulgare in phototrophic and heterotrophic biofilms suggests that the species plays an important role in the biology of these biofilms. This species is gram-negative, facultative anaerobic, and non-motile and can use a wide spectrum of carbon sources, including several exopolymeric substances produced by biofilms (Staats et al. 1999). It has been recognized as a producer of vitamin precursors, especially 2-keto-L-gulonic acid (vitamin C precursor), which can be used by other bacteria or microalgae. Ketogulonicigenium vulgare can also interact with diverse bacterial groups to form complex interaction networks, as occurs in biofilms (Cai et al. 2012).

Planctomyces (Planctomycetes) was another aerobic, chemoorganotrophic genus detected in both biofilms; this genus has been reported to be present in marine environments and its detection in the biofilms suggests a role in the decomposition of nitrogenous waste (Kuypers et al. 2003). Moreover, other bacteria known to be metabolizers of nitrogenous
Algunas especies fueron detectadas en todas las muestras de biopelículas y otras fueron exclusivas del tipo de biopelícula. Por ejemplo, K. vulgare, V. eiseniae, S. negevensis, $H$. hydrossis, P. brasiliensis y Streptococcus agalactiae fueron detectadas en la biopelícula autotrófica y en la biopelícula heterotrófica (Tabla 3), con la detección de solo K. vulgare (21-43\%) y H. hydrossis (9-29\%) en altos porcentajes en ambas biopelículas.

Con relación a las bacterias detectadas exclusivamente en biopelículas autotróficas, fueron detectadas $N$. multiformis, E. vietnamensis, $R$. baltica, Saprospira grandis y un candidato de la división WWE3 (Tabla 3), mientras que Micavibrio aeruginosavorus, Arcobacter sp. L, Hyphomonas neptunium, Riemerella anatipestifer, Phycisphaera mikurensis, Acetohalobium arabaticum, T. whipplei, M. testaceum y Propionibacterium acidipropionici fueron detectadas exclusivamente en las biopelículas heterotróficas (Tabla 3).

\section{Discusión}

Los resultados revelaron que la composición bacteriana en términos de diversidad y abundancia relativa fue consistente a través del tiempo en ambas biopelículas. Es probable que el periodo de proliferación previo al experimento (30 días) haya sido suficiente para que esos consorcios microbianos alcanzaran una fase de maduración en la cual la composición en la biopelícula haya sido menos variable a través del tiempo. Incluso, las condiciones constantes del experimento pudieron haber contribuido a mantener una composición uniforme.

Las bacterias pertenecientes a los filos Proteobacteria, Bacteroidetes y Planctomycetes parecieron formar la estructura esencial de $\mathrm{Hb}$ y PAb (también Chlamydiae). Estructuras taxonómicas similares han sido reportadas para biopelículas marinas y dulceacuícolas (Salta et al. 2013, Besemer 2015).

La diversidad bacteriana observada en las biopelículas supone diversas funciones biológicas de esos conglomerados microbianos y una red de interacciones muy compleja. Hay evidencias que demuestran que las biopelículas maduras permanecen fisiológicamente activas y nos son meros agregados en una superficie (Watnick y Kolter 2000, Vargas-Albores et al. 2019).

Se detectaron diferencias considerables en los perfiles bacterianos de ambas biopelículas; sin embargo, compartieron 10 de las 27 especies registradas en todos los muestreos. De estas especies, $H$. hydrossis parece jugar el papel más importante en la biología y la estructura física de ambas biopelículas. Esta especie fue detectada en proporciones altas en todas las biopelículas y es una bacteria estrictamente aeróbica, gram-negativa, filamentosa, y voluminosa (Kotay et al. 2011), que crece en ramas o filamentos más que en flóculos; estos filamentos han sido reportados como abundantes en ecosistemas acuáticos con altas tasas de superficie:volumen (Kotay et al. 2011). Adicionalmente, se ha documentado que 
and sulfurous compounds were exclusively detected in each type of biofilm. Despite the metabolic activity not being monitored in this study, these results could be considered evidence of the potential metabolic capabilities of these microbial conglomerates.

As expected, autotrophic bacteria were also detected in the $\mathrm{PAb}$; for instance, the detection of ammonia-oxidizing bacterium $N$. multiformis suggests participation in the nitrogen cycle of the system; previous reports have shown that members of the Nitrosospira genus are important nitrogen recyclers in aquatic ecosystems (Okabe et al. 2004, Gomez-Villalba et al. 2006). Furthermore, the presence of abundant gene clusters encoding proteins associated with exopolysaccharide synthesis have been reported for $N$. multiformis (Norton et al. 2008), and synthesized exopolysaccharides may serve as an energy source for other heterotrophic bacteria. Heterotrophic bacteria were also detected in this biofilm; for instance, este tipo de bacterias producen compuestos similares a las adhesinas (Larsen et al. 2008), que pueden servir para una buena adhesión a superficies sumergidas.

La abundancia relativamente alta de $K$. vulgare en las biopelículas autotróficas y heterotróficas pudiera sugerir un papel importante de la especie en la biología de las biopelículas. Esta es una especie gram-negativa, anaeróbica facultativa, no móvil y que puede utilizar una amplia gama de fuentes de carbono, incluyendo varios exopolímeros producidos por las biopelículas (Staats et al. 1999). La especie ha sido reconocida como productor de precursores de vitaminas, especialmente de ácido 2-Keto-L-gulonico (precursor de vitamina C), el cual puede ser usado por otras bacterias o microalgas. Ketogulonicigenium vulgare puede también interactuar con diversos grupos bacterianos para formar una red de complejas interacciones como las que suceden en las biopelículas (Cai et al. 2012).

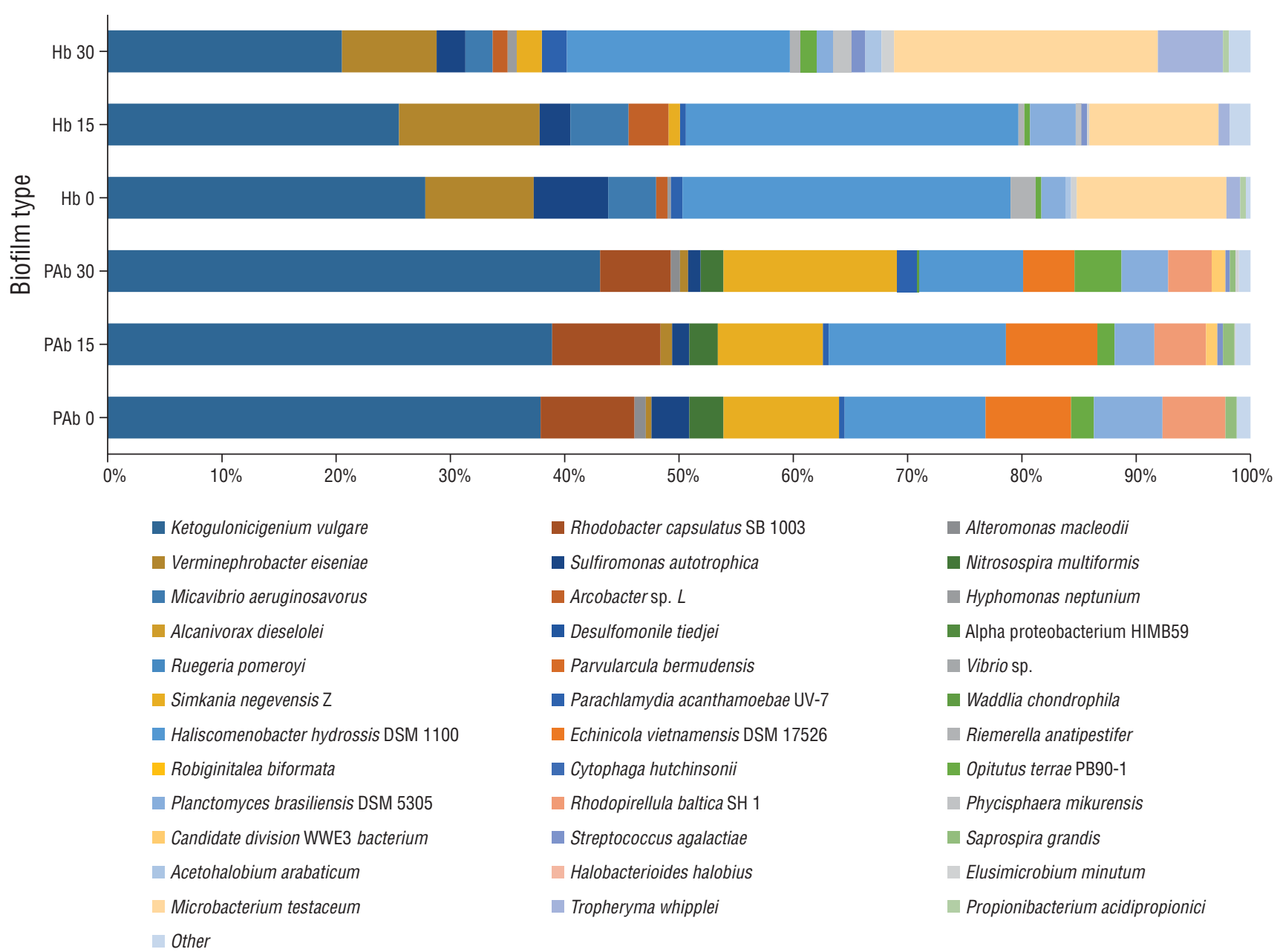

Figure 2. Bacterial profiles of phototrophic (PAb) and heterotrophic ( $\mathrm{Hb})$ biofilms over time (0, 15 and 30 days). Proportions are based on the total number of reads assigned up to species level.

Figura 2. Perfiles bacterianos de biopelículas fototróficas (PAb) y heterotróficas $(\mathrm{Hb})$ a través del tiempo ( 0,15 y 30 días). Las proporciones se basan en el número total de lecturas asignadas hasta el nivel de especie. 


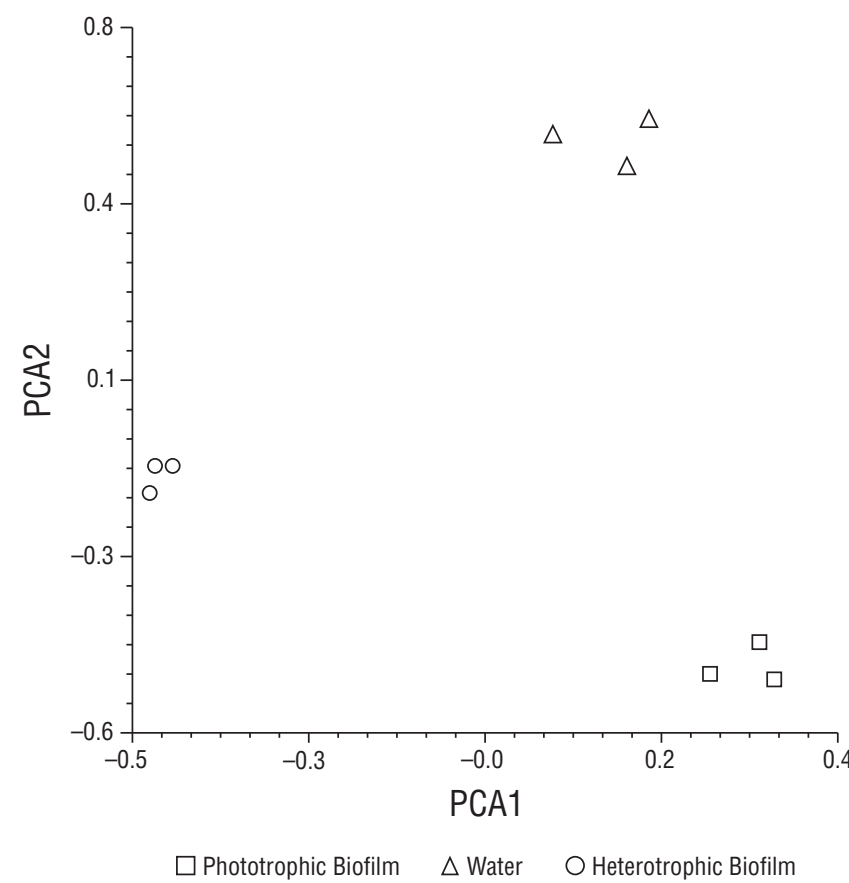

Figure 3. Principal component plot illustrating differences in bacterial community structure of heterotrophic and phototrophic biofilms after 30 days, considering time (PCA1 < 10\%) and sample type (PCA2 > 85\%).

Figura 3. Diagrama de componentes principales que ilustra las diferencias estructurales de las comunidades bacterianas de biopelículas fototróficas y heterotróficas después de 30 días, considerando el tiempo (PCA1 < 10\%) y el tipo de muestra (PCA2 > 85\%).

the exclusive presence of heterotrophic R. baltica in PAb indicates a biological role of the biofilm in the recycling of sulfurous compounds. This species is a marine, gram positive bacterium that is globally distributed and environmentally important, containing 110 genes coding for sulfatases (Glöckner et al. 2003), which play significant roles in the cycling of sulfur in the environment. However, the genome sequences of many Planctomycetes have a very large repertoire of putative sulfatases, whose role is still unknown.

The candidate division WWE3 bacterium (Waste Water of Evry 3), exclusively detected in the PAb, has been previously isolated from freshwater biofilms, inside sludge flocs, and in anaerobic digesters. However, fosmid annotations have not been conclusive regarding any particular metabolic activity (Guermazi et al. 2008), but their continuous detection in bacterial conglomerates suggests a possible role in the complex interaction network formed within phototrophic biofilms. Echinicola vietnamensis was also exclusively detected in $\mathrm{PAb}$, but its role is also unclear because of the scarce scientific information regarding its biology. Echinicola vietnamensis is a heterotrophic, gram-negative bacterium that was first detected in 2007 in a mussel farm (Nedashkovskaya et al. 2007).
Planctomyces (Planctomycetes) fue otro género de bacteria aeróbica, quimio-organotrófica detectada en ambas biopelículas; este género ha sido reportado en ambientes marinos y su detección en las biopelículas sugiere que juega un papel en la descomposición de desechos nitrogenados (Kuypers et al. 2003). Sin embargo, otras bacterias conocidas por metabolizar compuestos nitrogenados y sulfurados fueron detectadas en cada una de las biopelículas. A pesar de que la actividad metabólica no fue monitoreada en este estudio, estos resultados pueden ser considerados como evidencia de la capacidad metabólica potencial de estos conglomerados microbianos.

Tal como se esperaba, las bacterias autotróficas fueron también detectadas en PAb; por ejemplo, la presencia de bacterias oxidantes de amonio como $N$. multiformis sugiere su participación en el ciclo del nitrógeno del sistema. Reportes previos han reconocido al género Nitrosospira como un importante reciclador de nitrógeno en ecosistemas acuáticos (Okabe et al. 2004, Gomez-Villalba et al. 2006); más aún, la presencia de importantes grupos de genes codificantes de proteínas asociadas con exopolisácaridos ha sido reportada para N. multiformis (Norton et al. 2008), y los expolisacáridos pueden servir como una fuente de energía para otras bacterias heterotróficas. También se detectaron bacterias heterotróficas en esta biopelícula; por ejemplo, la presencia exclusiva de $R$. baltica en PAb supone una actividad biológica de la biopelícula en el reciclamiento de compuestos sulfurados. Esta es una especie de bacteria marina gram-positiva globalmente distribuida y ambientalmente importante que contiene 110 genes que codifican para las sulfatasas (Glöckner et al. 2003), las cuales juegan papeles importantes en el ciclo del azufre en el ambiente. Sin embargo, la secuencia genómica de muchos Planctomycetes tiene un gran repertorio de sulfatasas putativas cuyo papel permanece aún desconocido.

La bacteria candidato de la división WWE3 (Waste Water of Evry 3) detectada exclusivamente en PAb, ha sido previamente aislada de biopelículas dulceacuícolas, lodos secundarios y digestores anaeróbicos. Sin embargo, las anotaciones fosmid no han sido concluyentes sobre su actividad metabólica particular (Guermazi et al. 2008), pero su continua detección en los conglomerados bacterianos sugieren un posible papel en la compleja red de interacciones formada dentro de las biopelículas autotróficas. Echinicola vietnamensis fue también detectada únicamente PAb, pero su papel tampoco es claro debido a la escasa información científica respecto a su biología. Echinicola vietnamensis es una bacteria heterotrófica gram-negativa que fue detectada por primera vez en 2007 en una granja de mejillones (Nedashkovskaya et al. 2007).

Un resultado interesante es la presencia exclusiva de S. grandis en PAb; esta es una flexibacteria marina gram-negativa, multicelular-, quimio-organotrófica y filamentosa (Delk y Dekker 1972, Lewin 1997). Es posible que juegue un papel en la descomposición de materia orgánica, pero también como un predador de otras bacterias y algas, con lo que se puede suponer controla la población para prevenir los florecimientos descontrolados de bacterias y algas. Las 
An interesting result is the exclusive presence of S. grandis in PAb; this is a gram-negative, marine, multicellular, chemoorganotroph, filamentous-flexibacterium (Delk and Dekker 1972, Lewin 1997). It could play a role in the decomposition of organic material, and also act as a predator of other bacteria and algae, thereby controlling the population and preventing excessive bacterial/algal blooms. Predator bacteria were also detected in the heterotrophic biofilm. For instance, M. aeruginosavorus was only detected in the $\mathrm{Hb}$; this is an obligate predator that attaches to the surface of a broad range of gram-negative bacteria and feeds by leaching (Kadouri et al. 2007, Dashiff et al. 2011). It has previously only been detected in wastewaters, and this is the first time it has been detected in biofilms and aquaculture systems. The presence of several gram-negative bacteria, such as Arcobacter sp. L. and M. testaceum may provide optimal conditions for the proliferation of gram-negative predators. However, the presence of $M$. testaceum in the heterotrophic biofilm was unexpected considering that this gram-negative species has been only detected in terrestrial plants (Morohoshi et al. 2011). bacterias predadoras fueron también detectadas en las biopelículas heterotróficas. Por ejemplo M. aeruginosavorus fue encontrada únicamente en $\mathrm{Hb}$; este microorganismo es un predador obligado que se adhiere a las superficies colonizadas por un amplio intervalo de bacterias gram-negativas y se alimenta por lixiviación (Kadouri et al. 2007, Dashiff et al. 2011). Ha sido solamente reportada en aguas de desecho, y esta es la primera vez que se reporta en biopelículas y sistemas de acuacultura. La presencia de diversas bacterias gram-negativas como Arcobacter sp. L. y M. testaceum constituye condiciones adecuadas para la proliferación de predadores gram-negativos. Sin embargo, la presencia de M. testaceum en biopelículas heterotróficas es inesperada, considerado que esta especie gram-negativa ha sido reportada solamente en plantas terrestres (Morohoshi et al. 2011).

La mayoría de las especies marinas heterotróficas fueron detectadas en este tipo de biopelícula, por ejemplo, la bacteria ubicua Hyphomonas neptunium involucrada en los procesos de reciclamiento del nitrógeno (Badger et al. 2006). El género Hyphomonas utiliza una amplia variedad de sustratos, incluso el nitrógeno, principalmente de proteínas y aminoácidos,

Table 3. Species detected in both biofilms, in only the phototrophic biofilm (PAb only), and in only the heterotrophic biofilm (Hb only). Tabla 3. Especies detectadas en ambas biopelículas, sólo en la biopelícula fototrófica (PAb only) y sólo en la biopelícula heterotrófica (Hb only).

\begin{tabular}{ll}
\hline Phylum & Detected in both biofilms \\
\hline Proteobacteria & Ketogulonicigenium vulgare \\
& Verminephrobacter eiseniae \\
& Sulfiromonas autotrophica
\end{tabular}

Chlamydiae

Bacteriodetes

Parachlamydia hydrossis

Planctomycetes

Firmicutes

Simkania negevensis

Parachlamydia acanthamoebae

Planctomyces brasiliensis

Streptococcus agalactiae
Echinicola vietnamensis

Riemerella anatipestifer

Rhodopirellula baltica

Candidate division WWE3

bacterium

Micavibrio aeruginosavorus

Arcobacter sp. $L$

Hyphomonas neptunium

Phycisphaera mikurensis

Saprospira grandis
Acetohalobium arabaticum

Microbacterium testaceum

Propionibacterium acidipropionici 
More marine heterotrophic species were detected in these biofilms, for instance, the ubiquitous $H$. neptunium involved in nitrogen recycling processes (Badger et al. 2006). The Hyphomonas genus uses a wide range of substrates, including nitrogen, mainly from proteins and amino acids, as the major energy source of its metabolism. The presence of bacteria containing genes for the metabolism of nitrogenous and sulfurous compounds is of paramount importance for aquaculturing. The results indicate that other bacteria, apart from those already known, could also play significant roles in the cycle of these nutrients, either organic or inorganic.

Animal- and human-associated pathogens such as Parachlamydia acanthamoebae, S. negevensis, and S. agalactiae were detected in both biofilms, while others were exclusive to a particular biofilm type. For instance, Arcobacter sp. and $R$. anatipestifer were exclusive to the $\mathrm{Hb}$. Simkania negevensis is an amoebal apparent-obligate endoparasite unable to be cultured on conventional laboratory media (Kahane et al. 2001) and S. agalactiae strains are gram positive, facultative anaerobic bacteria that have been isolated from the marine environment, including from marine mammals and fish (Evans et al. 2008). Thus, it is possible that water is a vector of these bacteria and biofilms provided the optimal conditions for their proliferation. We have previously reported for the first time all of these species in farmed shrimp (Vargas-Albores et al. 2017), but their role, along with those of others, in biofilm and shrimp biology remains unclear.

The diversity of bacteria found in these biofilms suggests a complex microbial community and reveals the wide bacterial diversity of microbial conglomerates. Moreover, less than $50 \%$ of the reads were taxonomically classified up to species level, which suggests that the diversity in a single bacterial biofilm could be estimated at the level of hundreds. In addition, the microbial network of microbes is even more complex considering that microalgae, fungus, and other microbes are also important constituents of the biofilm. For instance, benthic microalgae, such as Navicula sp. and others, can form biofilms and produce exopolymeric substances that may serve as energy sources for heterotrophic bacteria (Bruckner et al. 2008).

It is worth noting that most of the bacteria detected in both biofilms were first detected in the water used to culture these microbes; however, the different conditions and biology of each consortium caused the growth of specific taxa which may provide functions required under the specific conditions.

The relative abundance of filamentous bacteria in PAb was lower than that of the $\mathrm{Hb}$, most likely due to the fact that the previous colonization of the substrate by the benthic diatom Navicula sp. provided advantages to the microalga over the bacteria; on the other hand, the $\mathrm{Hb}$ depended more on the biofouling capacity of filamentous bacteria.

It is difficult to discuss some of the bacteria present in the biofilms in great detail since they have either been recently discovered or are bacteria identified for the first time in biofilms and aquaculture systems. Further functional potential como su principal fuente de energía metabólica. La presencia de varias bacterias que contienen genes para el metabolismo de compuestos nitrogenados y azufrados es de primordial importancia para la acuacultura. Los resultados indican que otras bacterias, aparte de aquéllas ya conocidas, pueden jugar también un papel muy significativo en el ciclo de estos nutrientes, ya sea en formas orgánicas o inorgánicas.

Los patógenos asociados a animales o humanos, tales como P. acanthamoebae, S. negevensis y S. agalactiae, fueron detectados en ambos tipos de biopelículas, pero otros fueron exclusivos de un tipo de biopelícula en particular; por ejemplo, Arcobacter sp. y Riemerella anatipestifer se encontraron solamente en $\mathrm{Hb}$. Simkania negevensis es una "amiba" aparentemente endoparásito obligado, imposible de ser cultivado en medios convencionales de laboratorio (Kahane et al. 2001). Las cepas de S. agalactiae son bacterias gram positivas, anaeróbicas facultativas que han sido aisladas de ambientes marinos, incluso de mamíferos y peces (Evans et al. 2008). Así pues, es posible que el agua pueda ser un vector para este tipo de bacterias y que las biopelículas provean condiciones óptimas para su proliferación. Nosotros hemos detectado previamente todas estas especies en camarones cultivados (Vargas-Albores et al. 2017), pero su papel, así como el de otras, en la biología de las biopelículas y el camaron permanece poco claro.

La diversidad de bacterias encontrada en estas biopelículas sugiere una compleja comunidad microbiana y revela la amplia diversidad en los conglomerados microbianos. Además, menos que el $50 \%$ de las lecturas fueron taxonómicamente clasificadas hasta el nivel de especie, lo cual significa que la diversidad bacteriana en una sola biopelícula podría ser estimada en niveles de centenas. Adicionalmente, las redes microbianas son aún más complejas, considerando que las microalgas, los hongos y otros microorganismos son también constituyentes importantes de las biopelículas. Por ejemplo, las microalgas bentónicas como Navicula sp. y otras, pueden formar parte del consorcio y producir sustancias exopoliméricas que pueden servir como fuente de energía a bacterias heterotróficas (Bruckner et al. 2008).

Es notable que la mayoría de las bacterias detectadas en las biopelículas fueron detectadas primero en el agua en que se cultivaron estos microorganismos; sin embargo, las diferentes condiciones y biología de cada uno de los consorcios provocaron el crecimiento de grupos particulares que pudieron haber provisto funciones requeridas bajo las condiciones adecuadas.

La abundancia relativa de bacterias filamentosas fue menor en PAb que en $\mathrm{Hb}$, probablemente debido a la colonización previa del sustrato por la diatomea bentónica Navicula sp., dando ventajas a la microalga sobre las bacterias. Por otro lado, la $\mathrm{Hb}$ dependió mayormente de la capacidad de las bacterias filamentosas para la adhesión.

Es difícil discutir a mayor profundidad la presencia de algunas de las especies en las biopelículas, dado que algunas de ellas son bacterias recientemente descubiertas o bacterias 
analyses may provide additional information. However, the present study highlights the importance of bacterial characterization in shrimp aquaculture biofilms and provides an insight into the biology of these microbial conglomerates, which are currently revolutionizing aquaculturing.

\section{ACKNOWLEDGMENTS}

We would like to thank the National Council for Science and Technology (Mexico) for the economic support (project grant 222722).

\section{REFERENCES}

Al-Awadhi H, Dashti N, Khanafer M, Al-Mailem D, Ali N, Radwan S. 2013. Bias problems in culture-independent analysis of environmental bacterial communities: a representative study on hydrocarbonoclastic bacteria. SpringerPlus 2(1): 369. https://doi.org/10.1186/2193-1801-2-369

Avendaño-Herrera RE, Riquelme CE. 2007. Production of a diatom-bacteria biofilm in a photobioreactor for aquaculture applications. Aquacult. Eng. 36(2): 97-104. https://doi.org/10.1016/j.aquaeng.2006.08.001

Avnimelech Y. 1999. Carbon/nitrogen ratio as a control element in aquaculture systems. Aquaculture 176 (3-4): 227-235.

Badger JH, Hoover TR, Brun YV, Weiner RM, Laub MT, Alexandre G, Mrázek J, Ren Q, Paulsen IT, Nelson KE, et al. 2006. Comparative genomic evidence for a close relationship between the dimorphic prosthecate bacteria Hyphomonas neptunium and Caulobacter crescentus. J. Bacteriol. 188 (19): 6841-6850. https://doi.org/10.1128/jb.00111-06

Ballester ELC, Wasielesky W, Cavalli RO, Abreu PC. 2007. Nursery of the pink shrimp Farfantepenaeus paulensis in cages with artificial substrates: biofilm composition and shrimp performance. Aquaculture 269 (1-4): 355-362. https://doi.org/10.1016/j.aquaculture.2007.04.003

Becerra-Dorame MJ, Martinez-Cordova LR, Martínez-Porchas M, Hernández-López J, López-Elías JA, Mendoza-Cano F. 2014. Effect of using autotrophic and heterotrophic microbial-basedsystems for the pre-grown of Litopenaeus vannamei, on the production performance and selected haemolymph parameters. Aquacult. Res. 45(5): 944-948. https://doi.org/10.1111/are.12033

Becerra-Dorame MJ, Martinez-Cordova LR, Martínez-Porchas M, Lopez-Elías JA. 2011. Evaluation of autotrophic and heterotrophic microcosm-based systems on the production response of Litopenaeus vannamei intensively nursed without Artemia and with zero water exchange. Isr. J. Aquacult.-Bamid. IIC:63.2011.620: 1-7.

Besemer K. 2015. Biodiversity, community structure and function of biofilms in stream ecosystems. Res. Microbiol. 166: 774-781.

Bourne DG, Young N, Webster N, Payne M, Salmon M, Demel S, Hall M. 2004. Microbial community dynamics in a larval aquaculture system of the tropical rock lobster, Panulirus ornatus. Aquaculture 242 (1-4): 31-51.

https://doi.org/10.1016/j.aquaculture.2004.08.047

Bruckner CG, Bahulikar R, Rahalkar M, Schink B, Kroth PG. 2008. Bacteria associated with benthic diatoms from Lake Constance: phylogeny and influences on diatom growth and secretion of extracellular polymeric substances. Appl. Environ. Microbiol. 74(24): 7740-7749. https://doi.org/10.1128/aem.01399-08

Cai L, Yuan M-Q, Li Z-J, Chen J-C, Chen G-Q. 2012. Genetic engineering of Ketogulonigenium vulgare for enhanced identificadas por primera vez en biopelículas y sistemas acuícolas. Análisis posteriores sobre su potencial funcional proveerán información adicional. El presente estudio, sin embargo, resalta la importancia de la caracterización bacteriana en las biopelículas que se utilizan para el cultivo de camarón y provee una perspectiva sobre la biología de este tipo de conglomerados microbianos, que están revolucionando la acuacultura.

\section{Agradecimientos}

Nuestro especial agradecimiento al Consejo Nacional de Ciencias y Tecnología (México) por el apoyo económico (proyecto Ciencia Básica 222722).

production of 2-keto-1-gulonic acid. J. Biotechnol. 157(2): 320-325. https://doi.org/10.1016/j.jbiotec.2011.12.004

Dashiff A, Junka RA, Libera M, Kadouri DE. 2011. Predation of human pathogens by the predatory bacteria Micavibrio aeruginosavorus and Bdellovibrio bacteriovorus. J. Appl. Microbiol. 110(2): 431-444. https://doi.org/10.1111/j.1365-2672.2010.04900.x

Delk AS, Dekker CA. 1972. Characterization of rhapidosomes of Saprospira grandis. J. Mol. Biol. 64(1): 287-295. https://doi.org/10.1016/0022-2836(72)90336-1

Donlan RM. 2002. Biofilms: Microbial life on surfaces. Emerg. Infect. Diseases 8(9): 881-890. https://doi.org/10.3201/eid0809.020063

Evans JJ, Bohnsack JF, Klesius PH, Whiting AA, Garcia JC, Shoemaker CA, Takahashi S. 2008. Phylogenetic relationships among Streptococcus agalactiae isolated from piscine, dolphin, bovine and human sources: a dolphin and piscine lineage associated with a fish epidemic in Kuwait is also associated with human neonatal infections in Japan. J. Med. Microbiol. 57(11): 1369-1376. https://doi.org/10.1099/jmm.0.47815-0

Glöckner FO, Kube M, Bauer M, Teeling H, Lombardot T, Ludwig W, Gade D, Beck A, Borzym K, Heitmann K. 2003. Complete genome sequence of the marine planctomycete Pirellula sp. strain 1. Proc. Natl. Acad. Sci. 100(14): 8298-8303.

Goepel KD. 2013. Implementing the analytic hierarchy process as a standard method for multi-criteria decision making in corporate enterprises-a new AHP excel template with multiple inputs. Proc. Int. Symp. Anal. Hier. Proc. 1-10.

Gómez-Villalba B, Calvo C, Vilchez R, Gónzalez-López J, Rodelas B. 2006. TGGE analysis of the diversity of ammonia-oxidizing and denitrifying bacteria in submerged filter biofilms for the treatment of urban wastewater. Appl. Microbiol. Biotechnol. 72(2): 393-400. https://doi.org/10.1007/s00253-005-0272-7

Guermazi S, Daegelen P, Dauga C, Rivière D, Bouchez T, Godon J, Gyapay G, Sghir A, Pelletier E, Weissenbach J, et al. 2008. Discovery and characterization of a new bacterial candidate division by an anaerobic sludge digester metagenomic approach. Environ. Microbiol. 10(8): 2111-2123. https://doi.org/10.1111/j.1462-2920.2008.01632.x

Guillard RRL. 1975. Culture of phytoplankton for feeding marine invertebrates. In: Smith WL, Chanley MH (eds.), Culture of Marine Invertebrate Animals. Springer, Boston (MA), pp. 29-60. https://doi.org/10.1007/978-1-4615-8714-9_3 
Illumina. (2013). 16S Metagenomic sequencing library preparation: Preparing 16S Ribosomal RNA Gene Amplicons for the Illumina MiSeq System. [Accessed 4 December 2018] https:// support.illumina.com/documents/documentation/chemistry_ documentation/16s/16s-metagenomic-library-prep-guide15044223-b.pdf.

Kadouri D, Venzon NC, O'Toole GA. 2007. Vulnerability of pathogenic biofilms to Micavibrio aeruginosavorus. Appl. Environ. Microbiol. 73(2): 605-614. https://doi.org/10.1128/aem.01893-06

Kahane S, Dvoskin B, Mathias M, Friedman MG. 2001. Infection of Acanthamoeba polyphaga with Simkania negevensis and $S$. negevensis survival within amoebal cysts. Appl. Environ. Microbiol. 67(10): 4789-4795. https://doi.org/10.1128/aem.67.10.4789-4795.2001

Klindworth A, Pruesse E, Schweer T, Peplies J, Quast C, Horn M, Glöckner F. 2012. Evaluation of general 16S ribosomal RNA gene PCR primers for classical and next-generation sequencingbased diversity studies. Nucl. Acid. Res. 41(1): e1. https://doi.org/10.1093/nar/gks808

Kotay SM, Datta T, Choi J, Goel R. 2011. Biocontrol of biomass bulking caused by Haliscomenobacter hydrossis using a newly isolated lytic bacteriophage. Water Res. 45(2): 694-704. https://doi.org/10.1016/j.watres.2010.08.038

Kouzuma A, Watanabe K. 2015. Exploring the potential of algae/ bacteria interactions. Curr. Op. Biotechnol. 33: 125-129. https://doi.org/10.1016/j.copbio.2015.02.007

Kuypers MMM, Sliekers AO, Lavik G, Schmid M, Jørgensen BB, Kuenen JG, Damsté JSS, Strous M, Jetten MSM. 2003. Anaerobic ammonium oxidation by anammox bacteria in the Black Sea. Nature 422(6932): 608-611. https://doi.org/10.1038/nature01472

Langsrud S, Moen B, Møretrø T, Løype M, Heir E. 2016. Microbial dynamics in mixed culture biofilms of bacteria surviving sanitation of conveyor belts in salmon-processing plants. J. Appl. Microbiol. 120(2): 366-378.

Larsen P, Nielsen JL, Otzen D, Nielsen PH. 2008. Amyloid-like adhesins produced by floc-forming and filamentous bacteria in activated sludge. App. Environ. Microbiol. 74(5): 1517-1526. https://doi.org/10.1128/aem.02274-07

Lewin R. 1997. Saprospira grandis: A flexibacterium that can catch bacterial prey by "Ixotrophy". Microb. Ecol. 34(3): 232-236. https://doi.org/10.1007/s002489900052

Martínez-Córdova LR, Emerenciano M, Miranda-Baeza A, Martínez-Porchas M. 2014. Microbial-based systems for aquaculture of fish and shrimp: an updated review. Rev. Aquacult. 7(2): 131-148. https://doi.org/10.1111/raq.12058

Martínez-Córdova LR, Martínez-Porchas M, Porchas-Cornejo MA, Gollas-Galván T, Scheuren-Acevedo S, Arvayo MA, López-Elías JA, López-Torres MA. 2017. Bacterial diversity studied by next-generation sequencing in a mature phototrophic Navicula sp-based biofilm promoted into a shrimp culture system. Aquacult. Res. 48(5): 2047-2054.

https://doi.org/10.1111/are.13037

Martinez-Porchas M, Vargas-Albores F. 2015. Microbial metagenomics in aquaculture: a potential tool for a deeper insight into the activity. Rev. Aquacult.9(1): 42-56. https://doi.org/10.1111/raq.12102

Morohoshi T, Wang WZ, Someya N, Ikeda T. 2011. Genome sequence of Microbacterium testaceum StLB037, an $\mathrm{N}$-acylhomoserine lactone-degrading bacterium isolated from potato leaves. J. Bacteriol. 193(8): 2072-2073. https://doi.org/10.1128/jb.00180-11
Nedashkovskaya OI, Kim SB, Hoste B, Shin DS, Beleneva IA, Vancanneyt M, Mikhailov VV. 2007. Echinicola vietnamensis sp. nov., a member of the phylum Bacteroidetes isolated from seawater. Int. J. Syst. Evol. Microbiol. 57(4): 761-763. https://doi.org/10.1099/ijs.0.64546-0

Okabe S, Kindaichi T, Ito T, Satoh H. 2004. Analysis of size distribution and areal cell density of ammonia-oxidizing bacterial microcolonies in relation to substrate microprofiles in biofilms. Biotechnol. Bioeng. 85(95): 86-95. https://doi.org/10.1002/bit.10864

Parks DH, Tyson GW, Hugenholtz P, Beiko RG. 2014. STAMP: statistical analysis of taxonomic and functional profiles. Bioinformatics 30(21): 3123-3124. https://doi.org/10.1093/bioinformatics/btu494

Qian P-Y, Lau SCK, Dahms H-U, Dobretsov S, Harder T. 2007. Marine biofilms as mediators of colonization by marine macroorganisms: implications for antifouling and aquaculture. Mar. Biotechnol. 9(4): 399-410. https://doi.org/10.1007/s10126-007-9001-9

Roeselers G, Van Loosdrecht MCM, Muyzer G. 2008. Phototrophic biofilms and their potential applications. J. Appl. Phycol. 20(3): 227-235. https://doi.org/10.1007/s10811-007-9223-2

Salta M, Wharton JA, Blache Y, Stokes KR, Briand J-F. 2013. Marine biofilms on artificial surfaces: structure and dynamics. Environ. Microbiol. 15(1): 2879-2893. https://doi.org/10.1111/1462-2920.12186

Sruthisree C, Nayak H, Gowda G, Kumar B. 2015. Evaluation of periphyton and biofilm growth on different substrates in shrimp culture pond. J. Exp. Zoo. 18(2): 625-630.

Staats N, De Winder B, Stal L, Mur L. 1999. Isolation and characterization of extracellular polysaccharides from the epipelic diatoms Cylindrotheca closterium and Navicula salinarum. Eur. J. Phycol. 34(2): 161-169. https://doi.org/10.1017/s0967026299002097

Tolker-Nielsen T, Molin S. 2000. Spatial organization of microbial biofilm communities. Microb. Ecol. 40(2): 75-84.

Vargas-Albores F, Martínez-Córdova LR, Gollas-Galván T, Garibay-Valdez E, Emerenciano MGC, Lago-Leston A, Mazorra-Manzano M, Martínez-Porchas M. 2019. Inferring the functional properties of bacterial communities in shrimpculture bioflocs produced with amaranth and wheat seeds as fouler promoters. Aquaculture 500: 107-117. https://doi.org/10.1016/j.aquaculture.2018.10.005

Vargas-Albores F, Porchas-Cornejo MA, Martínez-Porchas M, Villalpando-Canchola E, Gollas-Galván T, Martínez-Córdova LR. 2017. Bacterial biota of shrimp intestine is significantly modified by the use of a probiotic mixture: a high throughput sequencing approach. Helgol. Mar. Res. 71(1): 5. https://doi.org/10.1186/s10152-017-0485-Z

Vert M, Doi Y, Hellwich K-H, Hess M, Hodge P, Kubisa P, Rinaudo M, Schué F. 2012. Terminology for biorelated polymers and applications (IUPAC Recommendations 2012). J. Pure App. Chem. 84(2): 377-410. https://doi.org/10.1351/pac-rec-10-12-04

Watnick P, Kolter R. 2000. Biofilm, city of microbes. J. Bacteriol. 182: $2675-2679$. https://doi.org/10.1128/jb.182.10.2675-2679.2000

Wu H, Zhang J, Mi Z, Xie S, Chen C, Zhang X. 2015. Biofilm bacterial communities in urban drinking water distribution systems transporting waters with different purification strategies. App. Microbiol. Biotechnol. 99(4): 1947-1955. https://doi.org/10.1007/s00253-014-6095-7

Received August 2018, accepted October 2018. 